\title{
Slik påvirker skiftarbeid sykepleieres søvn og helse
}

Turnusarbeid økte ikke risikoen for hodepine, mens de med skiftarbeidslidelse hadde høyere forekomst av rastløse bein. Det er noen av resultatene fra ti år med forskning på skiftarbeid, søvn og helse.

\section{Ståle Pallesen}

Seniorforsker og professor

Universitetet i Bergen og Haukeland universitetssjukehus

\section{Bjørn Bjorvatn}

Leder og professor

Nasjonal kompetansetjeneste for søvnsykdommer, Haukeland universitetssjukehus og

Universitetet i Bergen

\section{Bente Elisabeth Moen}

Lege og professor

Senter for internasjonal helse, Institutt for global helse og samfunnsmedisin, Universitetet i

Bergen

\section{Eirunn Thun}

Psykolog og forsker

Universitetet i Bergen

\section{Siri Waage}

Senterkoordinator og postdoktor

Universitetet i Bergen og Haukeland universitetssjukehus

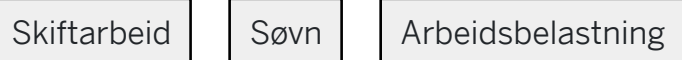




\section{Hovedbudskap}

Spørreundersøkelsen om skiftarbeid, søvn og helse (SUSSH) har nå vært gjennomført blant sykepleiere for tiende gang. Denne artikkelen oppsummerer resultater om arbeidsnarkomani og arbeidsrelaterte ulykker, quick returns og arbeidsrelaterte ulykker, hodepine og turnusarbeid, rastløse bein og turnusarbeid samt sammenhengen mellom personlighet og endring av symptomer på angst og depresjon over tid.

Spørreundersøkelsen om skiftarbeid, søvn og helse (SUSSH) omfatter norske sykepleiere og ble første gang gjennomført i 2008/2009. Hoveddelen av unders $\varnothing$ kelsen har bestått av årlige spørreundersøkelser der om lag 3000 sykepleiere har svart på spørsmål om arbeidsrelaterte forhold og fysisk og psykisk helse samt spørsmål om personlighet, mobbing og arbeidsnarkomani.

I 2018 gjennomførte vi den tiende runden av undersøkelsen. I tillegg har vi i denne tiårsperioden gjennomført mindre delunders $\varnothing$ kelser bestående av menstruasjonsdagbok, analyser av klokkegener samt blodprøver analysert for immunologiske parametre blant noen av deltakerne fra SUSSH-studien.

\section{Formålet med undersøkelsene}

Hovedformålet med SUSSH har vært å unders $\varnothing$ ke utvikling og endring over tid, særlig for å kunne studere hvorvidt, hvordan og i hvilken grad ulike turnusbelastninger, som nattarbeid og quick returns - mindre enn elleve timer hviletid mellom vakter - påvirker for eksempel helsen og risikoen for å bli sykemeldt.

I artikler fra SUSSH har vi blant annet vist at det å slutte med nattarbeid og roterende skiftarbeid er assosiert med en nedgang i rapportert søvnighet og insomni eller søvnløshet (1), og at nedgangen i antall quick returns reduserte fremtidig rapportert tretthet (2).

I løpet av de årene SUSSH har pågått, har seks forskere skrevet og forsvart sin doktorgrad delvis eller utelukkende basert på data fra unders $\varnothing$ kelsen. Dette er vist i tabell 1. I tillegg til de seks kandidatene er en sjuende kandidat i innspurten av sitt doktorgradsarbeid basert på SUSSH-data.

Vi er svært glad for at data fra SUSSH har bidratt til så mange doktorgrader. Så langt har vi også vært svært fornøyd med svarprosentene fra SUSSH, og vi takker alle sykepleierne som har deltatt. Vi har fått фkonomisk støtte årlig fra Norsk Sykepleierforbund til å gjennomføre SUSSH, noe vi også er veldig takknemlige for. 
Tabell 1. Oversikt over kandidater som har disputert på grunnlag av SUSSH-data

\begin{tabular}{lcl}
$\begin{array}{l}\text { Kandidat } \\
\text { Ingvild Sakvik-Lehouillier }\end{array}$ & Disputasår & Tittel på avhandling \\
\hline Elisabeth Flo & 2013 & $\begin{array}{l}\text { Shift work tolerance and adaptation to shift work among offshore } \\
\text { workers and nurses }\end{array}$ \\
\hline Eirunn Thun & 2016 & Sleep and health in shift working nurses \\
\hline Iselin Reknes & 2016 & $\begin{array}{l}\text { Exposure to workplace bullying among nurses: } \\
\text { Health outcomes and individual coping }\end{array}$ \\
\hline Mona Berthelsen & 2017 & $\begin{array}{l}\text { Effects of shift work and psychosocial and social work factors on mental } \\
\text { distress. Studies of onshore/offshore workers and nurses in Norway }\end{array}$ \\
\hline$\varnothing y$ stein Vedaa & 2017 & Shift work: The importance of sufficient time for rest between shifts
\end{tabular}

\section{Publikasjoner fra SUSSH}

Siden 2008/2009 har forskningsgruppen publisert 43 (1-43) vitenskapelige artikler fra SUSSH i internasjonale, fagfellevurderte tidsskrifter.

I tillegg er det publisert flere norske artikler i nasjonale tidsskrifter som Sykepleien og Sykepleien Forskning (44-52). Vi har som mål at resultater fra SUSSH skal være tilgjengelige for norske sykepleiere, både for dem som har deltatt i unders $\varnothing$ kelsen, og sykepleiere for $\varnothing v$ vrig samt for allmennheten generelt.

\section{«Vi har som mål at resultater fra SUSSH skal være tilgjengelige for norske sykepleiere.»}

Derfor har vi hatt som målsetting å oppsummere siste års publikasjoner i tidsskriftet Sykepleien samt å gjøre artiklene tilgjengelige på nettsiden www.sussh.no.

Vi håper sykepleiere finner resultatene fra unders $\varnothing$ kelsen interessante, og at de kan bidra til diskusjoner om forbedring av arbeidsvilkår for sykepleiere og være et grunnlag for fagforeningsarbeid, særlig knyttet til arbeidstidsbestemmelser. Det er også et mål med formidlingen at kunnskapsnivået om effekter av turnusarbeid generelt skal økes.

I 2018/2019 ble det publisert fem nye vitenskapelige artikler (39-43) fra SUSSH i internasjonale tidsskrifter. Disse artiklene omfatter temaer som arbeidsnarkomani og arbeidsrelaterte ulykker, quick returns eller nattarbeid og arbeidsrelaterte ulykker og hodepine, og hvorvidt hodepine er forbundet med turnusarbeid. 
Videre har vi skrevet om sammenhengen mellom rastløse bein og turnusarbeid samt hvorvidt personlighet påvirker angst og depresjon gjennom søvnløshet eller insomni. Nedenfor er en kort oppsummering av disse fem siste artiklene fra SUSSH.

\section{Arbeidsnarkomani og -relaterte ulykker}

I runde fire inneholdt SUSSH-skjemaet spørsmål om hvor ofte man hadde opplevd følgende åtte arbeidsrelaterte uhell og ulykker: døse på jobb, sovne under bilkjøring til eller fra jobb, skade seg selv, nesten skade seg selv, skade pasienter eller andre, nesten skade pasienter eller andre, skade utstyr og nesten skade utstyr. Data fra litt over 1700 sykepleiere inngikk i analysene.

Når vi kontrollerte for alder, kjønn, sivilstatus, omsorgsansvar for barn, stillingsprosent, antallet nattskift og total søvntid var arbeidsnarkomani assosiert med $\varnothing \mathrm{kt}$ risiko for å rapportere å ha vært involvert i alle de åtte typene arbeidsrelaterte uhell eller ulykker.

Mulige forklaringsmekanismer kan være at arbeidsnarkomane opplever følgende forhold i større grad enn andre, som er forbundet med uhell eller ulykker: har større arbeidskrav, jobber oftere når de er syke, har dårligere mental helse og har redusert evne til hente seg inn etter arbeid, altså redusert restitusjonsevne.

Ut fra disse resultatene kan det imidlertid ikke slås fast at det er arbeidsnarkomani som er årsaken til flere uhell eller ulykkestendenser. Det kan for eksempel være at arbeidsnarkomane har personlighetstrekk, slik som tvangstilbøyeligheter, som gjør at de subjektivt rapporterer flere uhell eller ulykker enn andre, uten at det reflekterer det objektivt antallet uhell eller ulykker de faktisk er involvert i (41).

\section{Quick returns og arbeidsrelaterte ulykker}

I likhet med artikkelen beskrevet over var søkelyset i denne artikkelen også arbeidsrelaterte uhell eller ulykker. Dataene var hentet fra runde åtte av SUSSH. Spesifikt unders $\varnothing$ kte vi hvorvidt quick returns var assosiert med de åtte arbeidsrelaterte uhellene eller ulykkene. Data fra 1784 sykepleiere var inkludert i analysene.

Antallet quick returns som ble rapportert siste året, var assosiert med større risiko for sju av åtte arbeidsrelaterte uhell eller ulykker: døse på jobb, skade seg selv, nesten skade seg selv, skade pasienter eller andre, nesten skade pasienter eller andre, skade utstyr og nesten skade utstyr, selv når vi statistisk kontrollerte for kjønn, alder, sivil status, det å ha hjemmeboende barn, stillingsprosent og antallet nattskift. 


\section{«Antallet quick returns som ble rapportert siste året, var assosiert med større risiko for sju av åtte arbeidsrelaterte uhell eller ulykker.»}

Nattskift rapportert siste året var assosiert med høyere risiko for fem av de åtte nevnte arbeidsrelaterte uhellene eller ulykkene: $\mathrm{d} \varnothing$ se på jobb, døse ved bilkjøring til eller fra jobb, skade pasienter eller andre, nesten skade pasienter eller andre og nesten skade utstyr.

Sammenhengene mellom nattskift og ulykker besto selv da vi statistisk kontrollerte for kjønn, alder, sivil status, det å ha hjemmeboende barn, stillingsprosent og antallet quick returns. En mulig mekanisme bak sammenhengene er at quick returns og nattarbeid gir for liten tid til restitusjon, og at det å jobbe natt i seg selv øker risikoen for uhell eller ulykker fordi døgnrytmen da tilsier at vi skal sove (39).

\section{Hodepine og turnusarbeid}

Denne artikkelen var basert på runde seks av SUSSH. Her inngikk et standardisert spørreskjema som kartla ulike former for hodepine: hyppig hodepine (>1 dag/md.), migrene, spenningshodepine, kronisk hodepine (>14 dager/md.) og hodepine relatert til medikamentoverforbruk. I alt 1585 sykepleiere hadde svart på spørsmålene om dette.

\section{«Ingen av hodepinetypene var forbundet med turnusordningene sykepleierne jobbet $i$.»}

Hyppig hodepine, migrene og kronisk hodepine var alle positivt assosiert med skiftarbeidslidelse, altså insomni eller søvnighet på grunn av turnus som overlapper med tidspunktet personen vanligvis sover, og insomnilidelse. Spenningshodepine var bare assosiert med å jobbe mer enn 20 netter det siste året, og hodepine relatert til medikamentoverforbruk var kun assosiert med insomnilidelse.

Ingen av hodepinetypene var forbundet med turnusordningene sykepleierne jobbet i. I analysene ble det kontrollert for alder, kjønn, stillingsprosent, sivil status og omsorgsansvar for barn. Samlet tyder altså funnene på at turnusarbeid i seg selv ikke øker risikoen for ulike hodepinetyper (43).

\section{Rastløse bein og turnusarbeid}

Det er godt dokumentert at turnusarbeid er forbundet med søvnproblemer som søvnløshet eller insomni og søvnighet eller tretthet. Vi vet imidlertid lite om slikt arbeid også er forbundet med søvnsykdommer som rastløse bein (restless legs). 
Rastløse bein er kjennetegnet av ubehagelig kribling eller en stikkende følelse i beina, som typisk kommer når man er i ro. Ubehaget er verst om kvelden, og symptomene forsvinner eller letter ved bevegelse, massasje eller liknende.

I runde fire av SUSSH inkluderte vi spørsmål om rastløse bein og unders $\varnothing$ kte om denne lidelsen hang sammen med turnusarbeid. I alt inngikk data fra om lag 1800 sykepleiere i analysene. Totalt 26,8 prosent rapporterte å lide av rastløse bein, hvorav 12,4 prosent hadde dette i alvorlig grad, og 8,4 prosent hadde det både hyppig og i alvorlig grad.

\section{«Rastløse bein var vanlig med høyere alder og blant dem som hadde skiftarbeidslidelse.»}

I analysene ble det kontrollert for kjønn, alder, sivil status, røyking, koffeininntak og skiftarbeidslidelse, og turnusordningen var ikke assosiert med rastløse bein generelt og heller ikke en hyppig og alvorlig forekomst.

Rastløse bein var vanlig med høyere alder og blant dem som hadde skiftarbeidslidelse. Hyppig og alvorlig forekomst av rastløse bein var mer vanlig blant røykere og blant dem som inntok mye koffein (42).

\section{Kan symptomer påvirke personlighet?}

Trekkmodeller for personlighet antar at personligheten består av ulike grunnleggende stabile egenskaper. Den mest anerkjente trekkmodellen er den såkalte femfaktormodellen.

Denne modellen innebærer at personligheten består av fem hoveddimensjoner:

- nevrotisisme, som innebærer å være nervøs og bekymret,

- ekstroversjon, som reflekterer å være energisk, snakkesalig og utadvendt,

- planmessighet, som karakteriserer å være organisert, nøyaktig og strukturert,

- åpenhet, som omfatter å ha et rikt fantasiliv og være intellektuelt orientert og

- medmenneskelighet, som betyr å være sympatisk og varm.

Den enkelte kan skåre fra lavt til høyt på hver dimensjon.

Tidligere unders $\varnothing$ kelser har primært fokusert på sammenhengen de tre førstnevnte trekkene har med angst, depresjon og søvn. Generelt har disse funnet en positiv sammenheng mellom nevrotisisme og angst, depresjon og dårlig søvn, mens ekstroversjon og planmessighet typisk har motsatte sammenhenger. 
I denne artikkelen benyttet vi data fra runde fire, fem og seks i SUSSH. Data fra cirka 1500 sykepleiere som hadde besvart alle relevante spørsmål, inngikk også i analysene. Vi unders $\varnothing$ kte om trekkene nevrotisisme, ekstroversjon og planmessighet, som ble målt i runde fire, påvirket endring i angst og depresjon fra runde fem til seks.

Videre unders $\varnothing$ kte vi om denne påvirkningen gikk via insomni, som var målt i runde fem. Sistnevnte vil i så fall reflektere såkalte indirekte effekter, for eksempel at personlighetstrekk påvirker insomni, som i sin tur påvirker angst eller depresjon.

Nevrotisisme var direkte og positivt relatert til en $\varnothing$ kning i symptomer på angst og depresjon fra runde fem til seks. Det var også en indirekte effekt av nevrotisisme via insomni, som var forbundet med en $\varnothing$ kning i depresjon - men ikke angst - fra runde fem til seks.

Vi fant verken direkte eller indirekte effekter, via insomni, av ekstroversjon eller planmessighet på endring i angst og depresjon fra runde fem til seks.

Vi konkluderer med at den direkte effekten av nevrotisisme på $\varnothing$ kningen i angst og depresjon over tid er langt sterkere enn den indirekte effekten, via søvnløshet eller insomni, som kun var signifikant for $\varnothing$ kning i depresjon, og ikke angst, i denne unders $\varnothing$ kelsen (40).

\section{Status for SUSSH videre}

I 2008 fikk vi etisk godkjenning for å gjennomføre ti runder med utsending av spørreskjema. Tiende og siste spørreskjemarunde ble gjennomført i fjor. Fremdeles er det mange ubesvarte spørsmål knyttet til effekter av turnusarbeid.

Vi har derfor søkt og fått godkjenning av Regionale komiteer for medisinsk og helsefaglig forskningsetikk, helseregion vest, om å forlenge konsesjonstiden for unders $\varnothing$ kelsen, og innen utgangen av 2020 må vi spørre SUSSH-deltakerne om de vil være med videre dersom unders $\varnothing$ kelsen skal forlenges.

Et alternativ, som vi vurderer, er å starte en ny unders $\varnothing$ kelse der vi rekrutterer deltakere blant sykepleierstudenter, slik at vi kan følge dem over tid fra før de begynner i sykepleieryrket - før de har blitt eksponert for turnusarbeid og andre arbeidsbelastninger.

Det kan også være aktuelt å videreføre SUSSH og samtidig starte en slik ny, longitudinell unders $\varnothing$ kelse med utgangspunkt i nåværende sykepleierstudenter. Uansett: Vi er dypt takknemlige for sykepleiernes hjelp og vilje til å delta i den undersøkelsen vi har gjennomført så langt! 


\section{Referanser}

1. Thun E, Bjorvatn B, Akerstedt T, Moen BE, Waage S, Molde H, et al. Trajectories of sleepiness and insomnia symptoms in Norwegian nurses with and without night work and rotational work. Chronobiol. Int. 2016;33(5):480-9.

2. Flo E, Pallesen S, Moen BE, Waage S, Bjorvatn B. Short rest periods between work shifts predict sleep and health problems in nurses at 1-year follow-up. Occup. Environ. Med. 2014;71(8):555-61.

3. Flo E, Bjorvatn B, Folkard S, Moen BE, Grønli J, Nordhus IH, et al. A reliability and validity study of the Bergen Shift Work Sleep Questionnaire in nurses working three-shift rotations. Chronobiol. Int. 2012;29(7):937-46.

4. Flo E, Pallesen S, Magerøy N, Moen BE, Grønli J, Nordhus IH, et al. Shift work disorder in nurses. Assessment, prevalence and related health problems. PLOS ONE. 2012;7(4):artikkel nr. e33981.

5. Natvik S, Bjorvatn B, Moen BE, Magerøy N, Sivertsen B, Pallesen S. Personality factors related to shift work tolerance in two- and three-shift workers. Appl. Ergon. 2011;42(5):719-24.

6. Roelen CaM, Magerøy N, Koopmans PC, Van Rhenen W, Groothoff JW, Pallesen S, et al. Low job satisfaction does not identify nurses at risk of future sickness absence: results from a Norwegian cohort study. Int. J. Nurs. Stud. 2013;50(3):366-73.

7. Saksvik-Lehouillier I, Bjorvatn B, Hetland H, Sandal GM, Moen BE, Magerøy N, et al. Personality factors predicting changes in shift work tolerance: a longitudinal study among nurses working rotating shifts. Work Stress. 2012;26(2):143-60.

8. Saksvik-Lehouillier I, Bjorvatn B, Hetland H, Sandal GM, Moen BE, Magerøy N, et al. Individual, situational, and lifestyle factors related to shift work tolerance among nurses who are new to - and experienced in night work. J. Adv Nurs. 2013;69(5):1136-46.

9. Schreuder JaH, Roelen CaM, Groothoff JW, Van Der Klink JJL, Magerøy N, Pallesen S, et al. Coping styles relate to health and work environment of Norwegian and Dutch hospital nurses: a comparative study. Nurs. Outlook. 2012;60(1):37-43.

10. Vedaa $\varnothing$, Bjorvatn B, Magerøy N, Thun E, Pallesen S. Longitudinal predictors of changes in the morningness-eveningness personality among Norwegian nurses. Pers. Individ. Dif. 2013;55(2):152-6. 
11. Storemark SS, Fossum IN, Bjorvatn B, Moen BE, Flo E, Pallesen S. Personality factors predict sleep related shift work tolerance in different shifts at two year follow-up: a prospective study. BMJ Open. 2013;3(11):artikkel nr. eoo3696.

12. Flo E, Pallesen S, Åkerstedt T, Magerøy N, Moen BE, Grønli J, et al. Shift related sleep problems vary according to work schedule. Occup. Environ Med. 2013;70(4):238-45.

13. Øyane NMF, Pallesen S, Moen BE, Akerstedt T, Bjorvatn B. Associations between night work and anxiety, depression, insomnia, sleepiness and fatigue in a sample of Norwegian nurses. PLOS ONE. 2013;8(8):artikkel nr. e70228.

14. Eldevik MF, Flo E, Moen BE, Pallesen S, Bjorvatn B. Insomnia, excessive sleepiness, excessive fatigue, anxiety, depression and Shift Work Disorder in nurses having less than 11 hours in-between shifts. PLOS ONE. 2013;8(8):artikkel nr. e70882.

15. Kunst JR, Løset GK, Hos $\varnothing y$ D, Bjorvatn B, Moen BE, Magerøy N, et al. The relationship between shift work schedules and spillover in a sample of nurses. Int. J. Occup. Saf. Ergon. 2014;20(1):3-11.

16. Reknes I, Pallesen S, Magerøy N, Moen BE, Bjorvatn B, Einarsen S. Exposure to bullying behaviors as a predictor of mental health problems: a prospective study among Norwegian nurses. Int. J. Nurs. Stud. 2014;51(3):479-87.

17. Roelen CaM, Bültmann U, Groothoff J, Van Rhenen W, Magerøy N, Moen BE, et al. Physical and mental fatigue as predictors of sickness absence among Norwegian nurses. Res. Nurs. Health. 2013;36(5):453-65.

18. Moen BE, Waage S, Ronda E, Magerøy N, Pallesen S, Bjorvatn B. Spontaneous abortions and shift work in a cohort of nurses in Norway. Occup. Med. Health. Aff. 2014;2(3):artikkel nr. 160.

19. Roelen CaM, Heymans MW, Twisk JWR, Van Rhenen W, Pallesen S, Bjorvatn B, et al. Updating and prospective validation of a prognostic model for sickness absence. Int. Arch. Occup. Environ. Health. 2015;88(1):113-22.

20. Roelen CaM, Van Rhenen W, Schaufeli WB, Van Der Klink JJL, Magerøy N, Moen BE, et al. Mental and physical health-related functioning mediates between psychological job demands and sickness absence among nurses. J. Adv. Nurs. 2014;70(8):1780-92. 
21. Thun E, Bjorvatn B, Torsheim T, Moen BE, Magerøy N, Pallesen S. Night work and symptoms of anxiety and depression symptoms among nurses. Work Stress. 2014;28(4):376-86.

22. Waage S, Pallesen S, Moen BE, Magerøy N, Flo E, Di Milia L, et al. Predictors of shift work disorder among nurses - a longitudinal study. Sleep Med.

2014;15(12):1149-55.

23. Saksvik-Lehouillier I, Pallesen S, Bjorvatn B, Magerøy N, Folkard S. Towards a more comprehensive definition of shift work tolerance. Ind. Health. 2015;53(1):6977.

24. Moen BE, Baste V, Morken T, Alsaker K, Pallesen S, Bjorvatn B. Menstrual characteristics and night work among nurses. Ind. Health. 2015;53(4):354-60.

25. Buchvold HV, Pallesen S, Øyane NMF, Bjorvatn B. Associations between night work and BMI, alcohol, smoking, caffeine and exercise - a cross-sectional study. BMC Public Health. 2015;15:artikkel nr. 1112.

26. Berthelsen M, Pallesen S, Magerøy N, Tyssen R, Bjorvatn B, Moen BE, et al. Effects of psychological and social factors in shiftwork on symptoms of anxiety and depression in nurses. A 1-year follow-up. J. Occup. Environ. Med. 2015;57(10):112737.

27. Roelen CaM, Heymans MW, Thun E, Reknes I, Laaksonen M, Magerøy N, et al. Predictive value of the SF-12 for sickness absence because of mental, musculoskeletal, and other somatic disorders. J. Occup. Environ. Med. 2015;57(10):1113-8.

28. Roelen CaM, Heymans MW, Twisk JWR, Laaksonen M, Pallesen S, Magerøy N, et al. Health measures in prediction models for high sickness absence: single-item self-rated health versus multi-item SF-12. Eur. J. Public Health. 2015;25(4):668-72.

29. Bjorvatn B, Magerøy N, Moen BE, Pallesen S, Waage S. Parasomnias are more frequent in shift workers than in day workers. Chronobiol. Int. 2015;32(10):1352-8.

30. Vedaa $\varnothing$, Krossbakken E, Grimsrud ID, Bjorvatn B, Sivertsen B, Magerøy N, et al. Prospective study of predictors and consequences of insomnia: personality, lifestyle, mental health, and work-related stressors. Sleep Med. 2016;20:51-8.

31. Thun E, Le Hellard S, Osland TM, Bjorvatn B, Moen BE, Magerøy N, et al. Circadian clock gene variants and insomnia, sleepiness, and shift work disorder. Sleep Biol. Rhythms. 2016;14(1):55-62. 
32. Reknes I, Einarsen S, Pallesen S, Bjorvatn B, Moen BE, Magerøy N. Exposure to bullying behaviors at work and subsequent symptoms of anxiety: the moderating role of individual coping style. Ind. Health. 2016;54(5):421-32.

33. Saksvik-Lehouillier I, Bjorvatn B, Magerøy N, Pallesen S. Hardiness, psychosocial factors and shift work tolerance among nurses - a 2-year follow-up study. J. Adv. Nurs. 2016;72(8):1800-12.

34. Andreassen CS, Bjorvatn B, Moen BE, Waage S, Magerøy N, Pallesen S. A longitudinal study of the relationship between the five-factor model of personality and workaholism. TPM Test. Psychom. Methodol. Appl. Psychol. 2016;23(3):285-98.

35. Buchvold HV, Pallesen S, Waage S, Bjorvatn B. Shift work schedule and night work load: Effects on body mass index - a four-year longitudinal study. Scand. J. Work Environ. Health. 2018;44(3):251-7.

36. Andreassen CS, Bakker AB, Bjorvatn B, Moen BE, Magerøy N, Shimazu A, et al. Working conditions and individual differences are weakly associated with workaholism: A 2-3-year prospective study of shift-working nurses. Front. Psychol. 2017;8:artikkel nr. 2045.

37. Reknes I, Notelaers G, Magerøy N, Pallesen S, Bjorvatn B, Moen BE, et al. Aggression from patients or next of kin and exposure to bullying behaviors: A conglomerate experience? Nurs. Res. Pract. 2017;2017:artikkel nr. 1502854.

38. Roelen CaM, Van Hoffen MFA, Waage S, Schaufeli WB, Twisk JWR, Bjorvatn B, et al. Psychosocial work environment and mental health-related long-term sickness absence among nurses. Int. Arch. Occup. Environ. Health. 2018;91(2):195-203.

39. Vedaa O, Harris A, Erevik EK, Waage S, Bjorvatn B, Sivertsen B, et al. Short rest between shifts (quick returns) and night work is associated with work-related accidents. Int. Arch. Occup. Environ. Health. 2019;92(6):829-35.

40. Sørengaard TA, Karlsen HR, Langvik E, Pallesen S, Bjorvatn B, Waage S, et al. Insomnia as a partial mediator of the relationship between personality and future symptoms of anxiety and depression among nurses. Front. Psychol. 2019;10:artikkel nr. 901.

41. Andreassen CS, Pallesen S, Moen BE, Bjorvatn B, Waage S, Schaufeli WB. Workaholism and negative work-related incidents among nurses. Ind. Health. 2018;56(5):373-81. 
42. Waage S, Pallesen S, Moen BE, Bjorvatn B. Restless Legs Syndrome/WillisEkbom Disease is prevalent in working nurses, but seems not to be associated with shift work schedules. Front. Neurol. 2018;9:artikkel nr. 21.

43. Bjorvatn B, Pallesen S, Moen BE, Waage S, Kristoffersen ES. Migraine, tensiontype headache and medication-overuse headache in a large population of shift working nurses: a cross-sectional study in Norway. BMJ Open. 2018;8(11):artikkel nr. e022403.

44. Thun E, Bjorvatn B, Moen BE, Magerøy N, Flo E, Pallesen S. Robuste og aktive sykepleiere tåler skiftarbeid. Sykepleien. 2013;101(2):44-6. DOI:

$\underline{10.4220 / \text { sykepleiens.2013.0004 }}$

45. Flo E, Magerøy N, Moen BE, Pallesen S, Bjorvatn B. Nattarbeid gir helseproblemer. Sykepleien. 2011;99(13):70-2. DOI: 10.4220/sykepleiens.2011.0192

46. Flo E, Magerøy N, Moen BE, Pallesen S, Bjorvatn B. Skiftarbeid gir søvnproblemer. Sykepleien. 2013;101(3):68-9. DOI: 10.4220/sykepleiens.2013.0011

47. Reknes I, Bjorvatn B, Einarsen S, Pallesen S, Magerøy N, Thun E, et al. Nye funn om turnusarbeid. Sykepleien. 2014;102(7):36-9. DOI:

10.4220/sykepleiens.2014.0099

48. Lien EF, Pallesen S, Bjorvatn B, Moen BE. Skiftarbeid og sykefravær blant sykepleiere. Sykepleien Forskning. 2014;9(4):350-6. DOI:

$\underline{10.4220 / \text { sykepleienf.2014.0176 }}$

49. Waage S, Thun E, Reknes I, Moen BE, Magerøy N, Pallesen S, et al. For få timer mellom vaktene påvirker søvn og helse. Sykepleien. 2015;103(10):58-60. DOI: $\underline{10.4220 / \text { Sykepleiens.2015.55403 }}$

50. Thun E, Pallesen S, Waage S, Reknes I, Moen BE, Bjorvatn B. Skiftarbeid, søvn og helse blant sykepleiere. Sykepleien. 2017;105(7):40-2. DOI:

$\underline{10.4220 / \text { Sykepleiens.2017.62099 }}$

51. Waage S, Moen BE, Pallesen S, Bjorvatn B. Ti år med SUSSH: Skiftarbeid, søvn og helse blant norske sykepleiere. Sykepleien. 2018;106(72561):e-72561. DOI: $\underline{10.4220 / \text { Sykepleienn.2018.72561 }}$

52. Waage S, Thun E, Reknes I, Moen BE, Magerøy N, Pallesen S, et al. Nattarbeid påvirker ikke menstruasjonen. Sykepleien. 2016;104(9):44-6. DOI:

$\underline{10.4220 / \text { Sykepleiens.2016.58607 }}$ 
